\title{
Effects of Wheat Flour Dough's Viscoelastic Level by Adding Glucose Oxidase on its Dynamic Shear Properties whatever the Strain Modes
}

\author{
Jean Didier KOUASSI-KOFFI ${ }^{1,2,3 *}$, Vlad MURESAN ${ }^{1}$, Sophie Nadège GNANGUI ${ }^{3}$, Elena MUDURA ${ }^{1}$ and \\ Lucien Patrice KOUAMÉ ${ }^{3}$ \\ ${ }^{1}$ Food Engineering Department, Faculty of Food Science and Technology, University of Agricultural Sciences and \\ Veterinary Medicine Cluj-Napoca - R0-400509 - Cluj-Napoca, Calea Floreşti, 64, Romania, \\ ${ }^{2}$ AgroParisTech, 1, avenue des Olympiades, 91744, Massy Cedex, UMR Ingénierie Procédés Aliments n 1145 \\ ${ }^{3}$ Université Nangui Abrogoua, Unité de Formation et de Recherche en Science et Technologie des Aliments 02 BP \\ 801 Abidjan 02, Côte d'Ivoire \\ * Corresponding author: k_kjd@yahoo.fr
}

Bulletin UASVM Food Science and Technology 71(1) / 2014

ISSN-L 2344-2344; Print ISSN 2344-2344; Electronic ISSN 2344-5300

\begin{abstract}
The objective of this work was to study the effects of wheat flour dough's viscoelastic level by adding glucose oxidase (Gox) on its rheological properties at dynamic shear strain mode to predict the final product quality. Dough does display a linear viscoelastic domain. Glucose oxidase (Gox) was added to dough in order to enhance its viscoelasticity and to take into account the possible effects of this viscoelasticity on the results. Whatever the types of dough strain used $G^{\prime}$ increased, $\tan \delta$ decreased and led to less sticky dough. Wheat flour dough, an increase in $G^{\prime}$ with extension may be associated to a strain-hardening phenomenon but the role of dough viscoelasticity is discussed.
\end{abstract}

Keywords: wheat flour, Viscoelasticity, rheological properties, glucose oxidase, dynamic shear.

\section{INTRODUCTION}

The rheological properties of a dough change greatly at breadmaking process. Because those changes can have significant effects on the machinability of the dough and the quality of the final product, accurate assessment of dough texture has spawned a great deal of several researches the last few years. Viscoelastic properties of bread dough greatly depend on the gluten proteins. The oxidation proteins reaction on bread dough induces the formation of a protein network with improved viscoelastic and structural properties, and therefore, betters performance for breadmaking (Wikström and Eliasson, 1998; Fayle et al., 2000). Enzymes are used in breadmaking with the objective of optimizing dough properties and improving the quality and conservation of the end product. The use of enzymes instead of chemical oxidants is a very interesting option to improve breadmaking performance of dough, because they are perceived as natural and non-toxic food components. Glucose Oxidase (GOX) (EC 1.1.3.4) catalyses the oxidation of $\beta$-D glucose to gluconic acid and hydrogen peroxide. It is the mechanism by which Gox improves bread quality. Diverse authors (Rosell et al., 2003; Aja et al., 2003; Hoseney and Faubion, 1981; Haarasilta, Pullinen and Vaisanen, 1991; Nakai, Takami Yanaka and Takasaki, 1995; Primo-Martin, Valera and Martinez-Anaya, 2003; Gujral and Rosell, 2004) indicate that hydrogen peroxide produced during Gox reaction causes the oxidation of the free sulfhydryl units from gluten protein giving disulfide linkages and the gelation of water soluble pentosans, changing rheological properties of wheat flour dough. Several research groups observed an increase in dough tenacity and elasticity and a decrease in dough extensibility upon Gox addition (Martinez-Anaya and Jimenez, 
1998; Primo-Martin et al., 2003; Rosell et al., 2003; Caballero et al., 2007; Davidou et al., 2008; Steffolani et al., 2010; Kouassi-Koffi et al., 2010). The rheological properties of wheat flour dough are largely governed by gluten. Gluten, the protein phase of flour, also has the ability to form a continuous macromolecular network, provided enough water for hydration exists, and sufficient mechanical energy is supplied during mixing. This independent source of dough viscoelastic behavior and its possible interaction make rheological properties of wheat flour doughs difficult to interpret. An attempt is made to uncouple these sources of viscoelastic behavior by careful evaluation of the effect of dough viscoelastic level by adding glucose oxidase on the dough dynamic shear properties. So knowledge of flour dough rheology and its evolution during various stages of breadmaking can help to improve its performance processes and thus bread quality. Several methods are often used to characterize wheat flour dough rheology depending on the dough viscoelastic nature.

\section{MATERIALS AND METHODS}

\section{Ingredients and sample dough mixing}

Wheat flour obtained from Groupe Soufflet was used without any chemical or proteins supplementation. It contained 12.3 wt.\% water, 11.6 wt.\% protein and 0.58 wt.\% ash (moist basis). It was stored in a freezer at $-20^{\circ} \mathrm{C}$ and then at $4^{\circ} \mathrm{C}$ for 1 to 3 days before use. Basic dough formula (on flour basis) consisted of $2.0 \mathrm{wt} . \%$ salt, $1.62 \mathrm{wt} . \%$ glucose, 51.96 wt.\% water and 0.75 wt.\% glucose oxidase (only for dough with Gox. It could be used 48 hours after preparation). The ingredients were weighed and placed in sealed boxes in a refrigerator at $4^{\circ} \mathrm{C}$ during the night before the test.

A dough at $41.3 \mathrm{wt} . \%$ water (total water moist basis), also containing $0.2 \mathrm{~g}$ of salt and $0.162 \mathrm{~g}$ of glucose was prepared with a Mixograph (5 min mixing at $85 \mathrm{rpm}$ ). The manual laminating system of the Chopin Alveograph (Dubat et al. 2008) was used under lubricated conditions to prepare samples. Paraffin oil ( $\eta=0.15 \mathrm{~Pa} \cdot \mathrm{s})$ was used as a lubricant.

\section{Measurement methods}

\section{Dynamic shear properties}

A controlled stress rheometer Carrimed CSL $^{2} 100$ (TA Instrument, New Castle, United States) with a cone-plate geometry $\left(4^{\circ}, 40 \mathrm{~mm}\right.$ dia- meter) setup with a $2 \mathrm{~mm}$ gap with temperature control $\left(-5\right.$ to $\left.99^{\circ} \mathrm{C}\right)$ was used for flow and dynamic tests. Using a truncated cone eliminated unwanted phenomena that may occur near the tip of the cone and facilitated its setting. The dough was prevented from drying during the test by use of a solvent trap filled with water and a lid over the cone to create a chamber saturated by water vapor. Equipment control and initial data handling was performed using TA instruments Rheology Solution software version V123u. The shear stress was measured in the shear rate interval of $y=0-250 \mathrm{~s}^{-1}$. Dough was placed on the lower plate which then was moved towards to the upper plate until to obtain the setup with a $2 \mathrm{~mm}$ gap. The dough was then in contact with the upper plate. The remainder dough around of the upper plate was carefully cut. The sample was then left $5 \mathrm{~min}$ before measurement to allow induced stress to relax. The tests were performed at $25^{\circ} \mathrm{C}, 1 \mathrm{rad} / \mathrm{s}$, a deformation of $0.01 \%$ and for a given stress interval of $0,5-100 \mathrm{~Pa}$, corresponding to the quasi-linearity domain of the dough (Berland et al., 1995).

\section{Statistical Analysis}

All determinations reported in this study were carried out in triplicates. Mean value and standard deviation were calculated. Analysis of variance (ANOVA) and correlations were also performed. Tukey's (HSD) test at $\mathrm{P}<0.05$ was used for mean values separation. It was made in order to evaluate differences among samples, while the relationship between measured parameters was assessed by Pearson's test (significant level at $\mathrm{p} \leq 0.05$ ).

\section{RESULTS AND DISCUSSION Formulation process}

A classic formulation of wheat flour dough mixing and kneading at breadmaking process was used (Fig. 1).

Glucose oxidase is weighed and used the day of the experiment. In this case the enzyme is in its optimal hydrolysis and activities conditions and avoids its denaturation. The mixtures (flour + glucose) and (water + salt) were weighed the day before the experiment and stored in the refrigerator at $4^{\circ} \mathrm{C}$. It is important to have flour +glucose and water+ salt mixtures during the dough formulation process to ensure dough temperature after kneading lower than $25^{\circ} \mathrm{C}$. It is therefore essential to use mixtures (flour + 
glucose) and (water + salt) satisfying the basic rule used in the bakery following:

$\mathrm{T}_{\mathrm{p}}+\mathrm{T}_{\mathrm{f}}+\mathrm{T}_{\mathrm{e}}<50^{\circ} \mathrm{C}$ where:

$\mathrm{T}_{\mathrm{p}}$ is the test room temperature $\left(18^{\circ} \mathrm{C}\right)$.

$\mathrm{T}_{\mathrm{f}}^{\mathrm{p}}$ is the flour temperature $\left(4^{\circ} \mathrm{C}\right)$.

$\mathrm{T}_{\mathrm{e}}$ is the water temperature $\left(4^{\circ} \mathrm{C}\right)$

whether $\mathrm{T}_{\mathrm{p}}+\mathrm{T}_{\mathrm{f}}+\mathrm{T}_{\mathrm{e}}=18^{\circ} \mathrm{C}+4^{\circ} \mathrm{C}+4^{\circ} \mathrm{C}=26^{\circ} \mathrm{C}$ which is a value strictly less to $50^{\circ} \mathrm{C}$ respecting the basic rule of baking products.

The proportions of ingredients are used to obtain at the end of kneading a dough with $41.3 \%$ water, homogeneous, smooth and adhesive appearance related to Lassoued's results (2005). The addition of glucose oxidase 0.075 wt. \% is required for a maximum catalytic activity of the enzyme in the dough (Garcia, 2000) with these ingredients proportions at $\mathrm{pH}$ (5.6) and temperature $\left(25^{\circ} \mathrm{C}\right)$ during the tests.

\section{Kneading process}

Figure 2 shows wheat flour kneading time scale and the resulting dough behavior. The scale present four distinct areas depending on the kneaded dough quality:

- 0 to 5 minutes: lower kneaded dough. Dough is more viscous than elastic;

- 5 to 5.8 minutes: optimum kneaded dough. Dough has an optimum viscoelastic character;

- 5.8 to 8.3 minutes: Normal kneaded dough. Dough has a normal character but it is tackiness;

- $t>8.3$ minutes: higher kneaded dough. Dough has a very sticky character less characteristic of storage and loss moduli.

These results agrees with increased wheat flour dough rheological properties at given kneading time reported by other authors (Davidou et al., 2008; Steffolani et al., 2010 and KouassiKoffi et al., 2010).

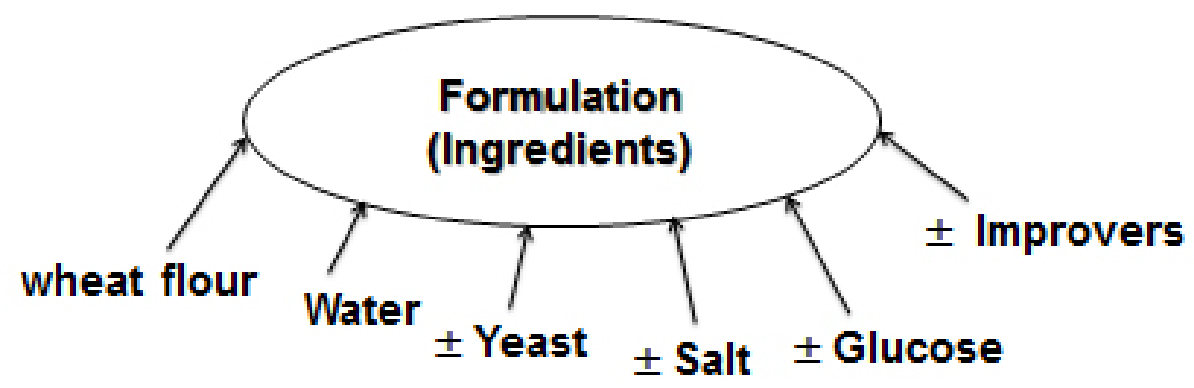

Fig. 1. Ingredients for the flour dough formulation process. $( \pm)$ with or without the given ingredient.

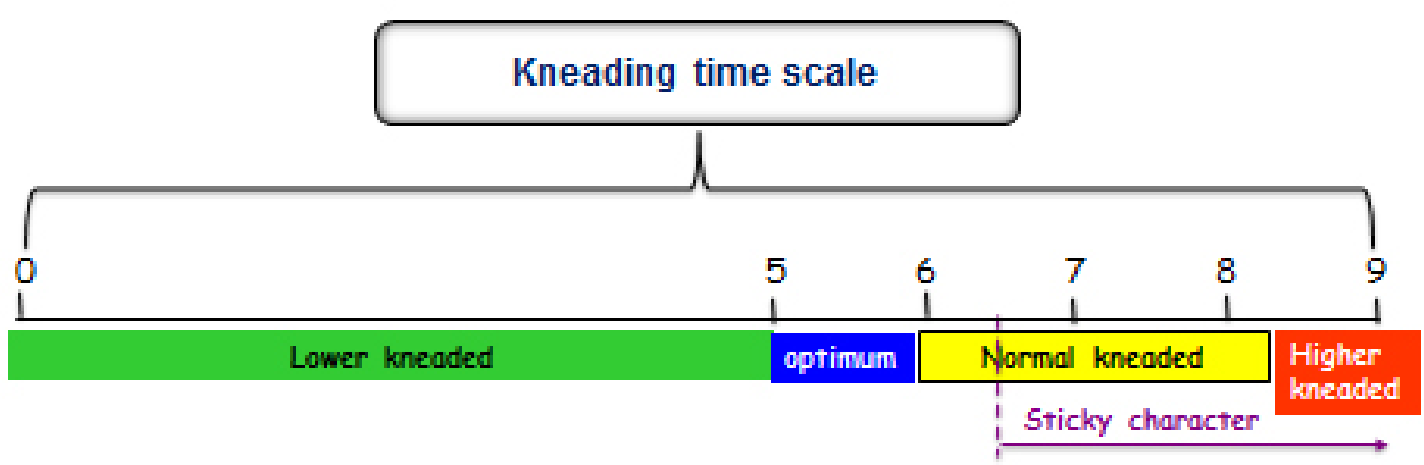

Fig. 2. Time scale of dough behavior during the flour kneading process with or without Glucose oxidase. 


\section{Dynamic viscoelastic behavior} (dynamic shear)

Figure 3 shows changes in storage modulus $\left(G^{\prime}\right)$ and loss modulus ( $\left.G^{\prime}\right)$ as a function of strain $\gamma_{0}$ $(\%)$ for a variable strain $\gamma_{0}(\%)$ and frequency $(0-$ $1592 \mathrm{~Hz}$ ) at $25^{\circ} \mathrm{C}$. Magnitudes of storage ( $\left.\mathrm{G}^{\prime}\right)$ and loss (G') moduli increased similarly in the dough linear domain between 0.01 and $0.08 \%$. This dynamic linear domain is necessary to prove the quality of the flour used. It respects the linearity domain described by Berland and Launay (1995),
Ghorbel (1998) and Hoseney and Smewing (1999) with values between 0.0 and $0.2 \%$. Similarly to Van Vlet et al. (1992) who were obtained strain $<0.2 \%$. Magnitudes of G' were higher than those of G" over most of the strain (\%) range. The dough with Gox is more elastic then more structured. This result agrees with increased viscoelastic moduli reported by the literature (Hardeep et Cristina, 2004; Miller and Hoseney, 1999; Vemulapalli and Hoseney, 1998; Hilhorst et al., 1999). Thus the addition of Gox promotes an increase in dough stability when

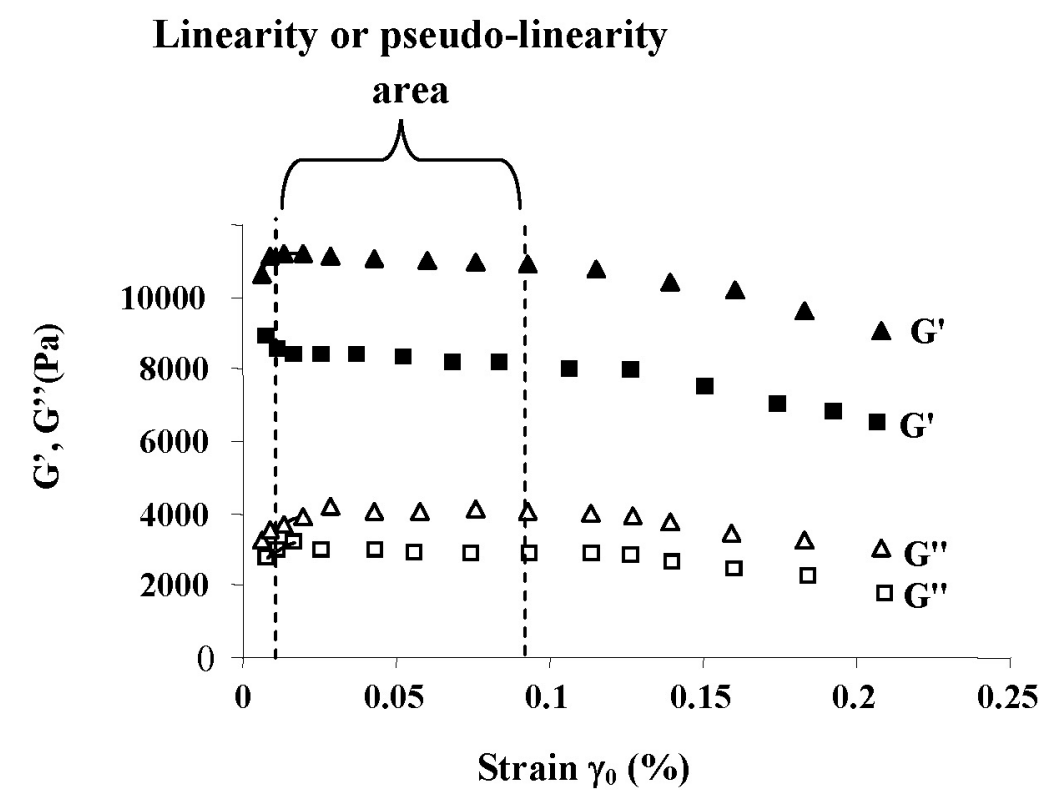

Fig. 3. Dynamic shear moduli G' and G" versus dough strain $\gamma_{0}$. Dough with GOX $(\boldsymbol{\Delta}, \triangle)$; dough without GOX $(\boldsymbol{\square}, \square)$. Frequency $(0-1592 \mathrm{~Hz})$; G' (elastic modulus);

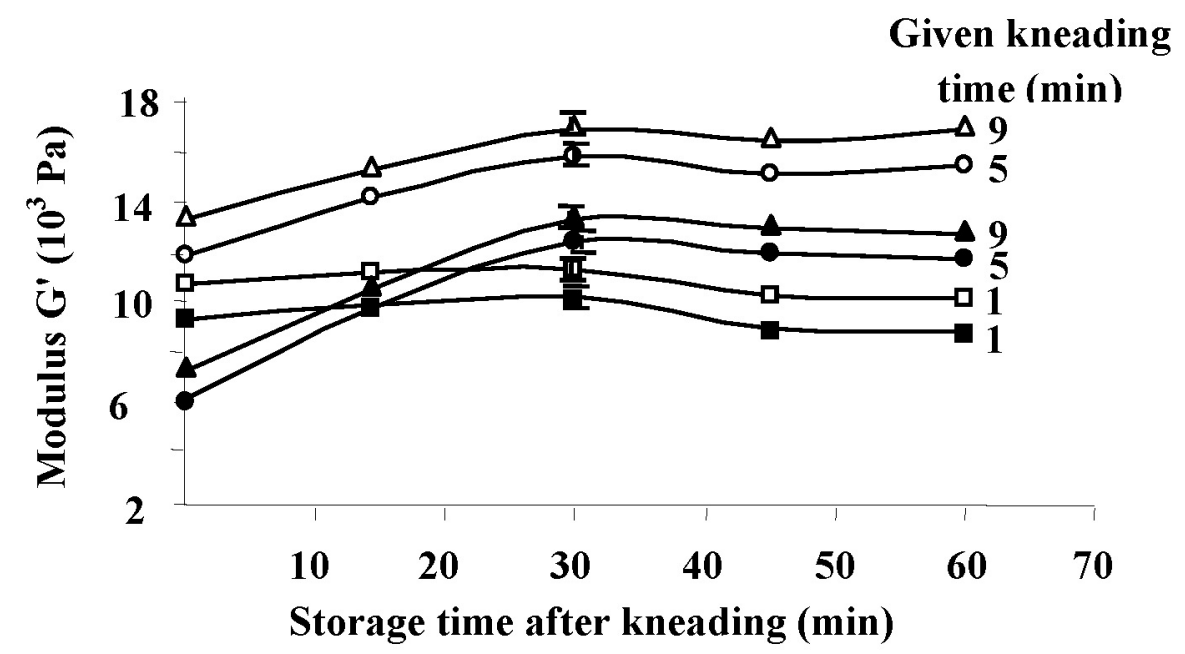

Fig. 4. Elastic modulus $G^{\prime}$ versus storage time after kneading. Dough with $\operatorname{GOX}(\diamond, \triangle, \square)$; dough without $\operatorname{GOX}(\bullet, \mathbf{\Delta ,} \mathbf{\square})$ 
overmixing. This result agrees with the increased dough viscoelastic behavior reported by Wikström and Eliasson (1998).

The Figure 4 shows dough's storage modulus (G') magnitude during its storage time after kneading for given kneading time. At given kneading time, values of the storage modulus $G^{\prime}$ of dough with Gox is higher showing Gox structural effects dependency. One minute of mixing has no effect on dough's elastic properties ( $G$ ') with increased storage time. A minute of kneading is not necessary for the formation of gluten and others proteins films. However the magnitudes of $G^{\prime}$ increased with increase in storage time with a high given kneading time dependency. Such behaviour is in good agreement with those found for the literature describing that rheological properties of wheat flour dough are largely governed by the contribution of starch, protein and water. Starch, the most abundant component in dough (50-55\% wt), is in high enough concentration to form a continuous network of particles which gives rise to viscoelastic behavior. Gluten, the protein phase of flour, also has the ability to form a continuous macromolecular network, provided enough water for hydration exists, and sufficient mechanical energy is supplied during mixing. So all these phenomena required a specific kneading and storage times of dough. The addition of Gox leads to an increase in the elastic ( $\left.G^{\prime}\right)$ and viscous (G') moduli of wheat flour dough (Gujal et al., 2004; Vemulapalli et al., 1998; Dunnewind et al., 2002; Kouassi-Koffi et al., 2010) with an used time dependency.

\section{CONCLUSION}

Whatever the strain mode the viscoelastic level of the wheat flour dough increase its dynamic shear properties. The addition of glucose oxidase to wheat dough produces an important modification on the gluten proteins related with the formation of high molecular weight polymers that reinforced the gluten network. The resulting dough was an optimum viscoelastic character at given interval kneading time of 5 to 5.8 minutes.

Acknowledgments. Wethank to Romanian Government and Agence Universitaire de la Francophonie (AUF) who are supported this research project through the Eugen Ionescu Postdoctoral scholarship program.

\section{REFERENCES}

1. Aja, S. et al. (2003). Improvement of cereal protein network through enzyme treatment. In C. M. Courtin, W. S. Veraverbeke, and J. A. Delcour, Recent advances in enzymes in grain processing. (pp. 390 101- 106). Leuven, -Belgium.

2. Berland, S. and Launay, B. (1995). Shear Softening and thixotropic properties of wheat flour dough in dynamic testing at high shear strain. Rheologica Acta 34:622-625.

3. Caballero, P. A. et al. (2007). Improvement of dough rheology, bread quality and bread shelf-life by enzymes combination. Journal of Food Engineering 81:42-53.

4. Davidou, S. et al. (2008). Influence of shaping and orientation of structures on rheological properties of wheat flour dough measured in dynamic shear and in biaxial extension. Cereal Chemistry 85:403-408.

5. Dubat, A. et al. (2008) The Alveo-consistograph handbook, 2nd edn. AACC, St Paul, MN, 87 pp.

6. Dunnewind, B. et al. (2002). Effect of oxidative enzymes on bulk rheological properties of wheat flour doughs. Journal of Cereal Science 36:357-366.

7. Fayle, S. E. et al. (2000). Crosslinkage of proteins by dehydroascorbic acid and its degradation products. Food Chemistry 70:193-198.

8. Garcia, R. (2000). Etude de trois systèmes enzymatiques d'oxydoréduction-catalase, peroxydase et glucose oxydase- pris isolement et en mélange, susceptibles d'intervenir en technologie de la panification. Thèse de Doctorat, Université Paris VII, France, 181p.

9. Ghorbel, D. (1998). Propriétés d'adhérence des pâtes de farine de blé. Méthodes d'évaluation, rôle des énergies de surface et du comportement rhéologique des pâtes. Thèse de Doctorat. Université de Paris VII, Université de Paris XI, ENSIA, France, pp. 267-298.

10. Gujral, H. S., and Rosell, C. M. (2004). Improvement of the breadmaking quality of rice flour by glucose oxidase. Food Research International 37:75-81.

11. Haarasilta, S. et al. (1991). Enzyme product and method of improving the properties of dough and the quality of bread. Patent EE UU, 4,990,343.

12. Hardeep S.G. and Cristina M.R. (2004). Improvement of breadmaking quality of rice flour by glucose oxidase. Food Research International 37:75-81.

13. Hilhorst R. et al. (1999). Baking performance, rheology, and chemical composition of wheat dough and gluten affected by xylanase and oxidative enzymes. Journal of Food Science 64:801-813.

14. Hoseney, R.C.and Smewing, J. (1999). "Instrumental measurement of stickiness of doughs and other foods", J Text Stud. 30:123-136.

15. Koehler, P. (2003). Concentrations of low and high molecular weight thiols in wheat dough as affected by different concentrations of ascorbic acid. Journal of Agriculture and Food Chemistry 51:4948-4953.

16. Kouassi-Koffi, J.D. et al. (2010). Lubricated squeezing flow of thin slabs of wheat flour dough: comparison of results at constant plate speed and constant extension rates. Rheologica Acta 49:275-283. 
17. Lassoued N. et al. (2005). Effet de la matière grasse et du saccharose sur les propriétés rhéologiques des pâtes céréaliers. Projet CANAL-Salve du ministère de la recherche Française. Groupe Français de rhéologie-Nice 26-28 Octobre, communication à des congrès, CEMEF, France, pp. 177- 180.

18. Martínez-Anaya, M. A., and Jiménez, T. (1997). Rheological properties of enzyme supplemented doughs. J Text Stud. 28:569-583.

19. Miller, K.A and Hoseney, R.C. (1999). "Effect of oxidation on the dynamic rheological properties of wheat flour water doughs", Cereal Chem. 76:100-104

20. Nakai, K. etal.(1995). Bread qualityimproving composition and bread producing process using the same. European Patent Application. 0,686,348 A1

21. Primo-Martin, C. et al. (2003). Effect of pentosanase and oxidases on the characteristics of doughs and the glutenin macropolymer (GMP). Journal of Agriculture and Food Chemistry 51:4673-4679.
22. Rosell, C. M. et al. (2003). Wheat flour proteins as affected by transglutaminase and glucose oxidase. Cereal Chemistry 80:52-55.

23. Steffolani, M. E., et al. (2010). Effect of glucose oxidase, transglutaminase, and pentosanase on wheat proteins: Relationship with dough properties and breadmaking quality. Journal of Cereal Science 51:366-373.

24. Van Vliet, T. et al. (1992). Strain hardening of dough as a requirement for gas retention. J Text Stud. 23:439-460.

25. Vemulapalli, V. and Hoseney, R.C. (1998). Glucose oxidase effects on gluten and water solubles. Cereal Chemistry 75:859-862.

26. Vemulapalli, V. et al. (1998). Glucose oxidase in breadmaking systems. Cereal Chemistry 75:439-442.

27. Wikström, K., and Eliasson, A. C. (1998). Effects of enzymes and oxidizing agents on shear stress relaxation of wheat flour dough: additions of protease, glucose oxidase, ascorbic acid, and potassium bromate. Cereal Chemistry 75:331-337. 